\title{
A vesesejtes daganatok célzott terápiás kezelése, a terápia okozta mellékhatások és ellátásuk
}

\author{
Nagyiványi Krisztián dr. - Géczi Lajos dr. \\ Országos Onkológiai Intézet, Kemoterápia C. és Klinikai Farmakológiai Osztály, Budapest
}

\begin{abstract}
Az utóbbi évtized egyik legnagyobb terápiás áttörését jelentette a célzott daganatellenes kezelések bevezetése az onkológiai gyakorlatba. Míg korábban a vesesejtes daganatokat alapvetően terápiarezisztensnek tekintették, manapság legalább kilenc, célzottan ható gyógyszer áll rendelkezésre a klinikusok számára. Legújabb lehetőségként már egyes immunterápiás készítmények bekerültek a terápiás ajánlások közé. Ebben a közleményben a jelenleg alkalmazott terápiás modalitásokat foglaltuk össze, kiegészítve a kezelések okozta mellékhatásokkal és ellátásukkal.

Orv Hetil. 2017; 158(38): 1488-1502.
\end{abstract}

Kulcsszavak: vesesejtes carcinoma, célzott (targeted) kezelések, vascularis endothelialis növekedési faktort gátlók, tirozinkináz-gátlók, mTOR-gátlók, immunterápia, mellékhatások, biomarkerek

\section{Targeted treatment of renal cell carcinoma, treatment caused side-effects and side-effect management}

Until the past decade, therapeutic options for unresectable and/or metastatic renal cell carcinoma were limited. Renal cell carcinoma is generally resistant to conventional chemotherapy, and only a small percentage of patients with renal cell carcinoma benefit from cytokine treatment. Since 2005 , the advances in target-based therapy and immunotherapy modalities have created a paradigm shift in the treatment of renal cell carcinoma. Herein, we review the most up-to-date practices and emerging therapies for the treatment of renal cell carcinoma and focus on the threrapy caused side-effects and side-effect management.

Keywords: renal cell carcinoma, targeted treatments, vascular endothelial growth factor inhibitors, tyrosine kinase inhibitors, mammalian target of rapamycin inhibitors, immunotherapy, side-effects, biomarkers

Nagyiványi K, Géczi L. [Targeted treatment of renal cell carcinoma, treatment caused side-effects and side-effect management]. Orv Hetil. 2017; 158(38): 1488-1502.

(Beérkezett: 2017. május 30.; elfogadva: 2017. július 10.)

ACE = angiotenzinkonvertáló enzim; ARCC $=($ advanced renal cell carcinoma) elörehaladott vesesejtes carcinoma; $\mathrm{ATE}=(\mathrm{ar}-$ terial thromboembolism) artériás thromboembolia; $\mathrm{BSC}=$ (best supportive care) elérhető legjobb támogató kezelés; CALGB $=($ Cancer and Leukemia Group B $)$ egy amerikai egyesült államokbeli rákkutató csoport; $\mathrm{c}-\mathrm{KIT}=($ receptor tyrosine kinase) tirozinkináz-receptor; c-MET $=$ (tyrosine-protein kinase Met) Met tirozin-protein kináz; COMPARZ = COMParing the efficacy, sAfety and toleRability of paZopanib vs. sunitinib; $\mathrm{CT}=$ (computed tomography) komputertomográfia; CTLA-4 = (cytotoxic T-lymphocyte-associated protein 4) cito- toxikus T-lymphocytával társult négy antigén; EGFR = (epidermal growth factor receptor) epidermalis növekedési faktor receptor; EKG $=$ elektrokardiográfia $; E M A=($ European Medicines Agency) Európai Gyógyszerügynökség; EMK = egyedi méltányossági kérelem; ESMO = (European Society for Medical Oncology) Európai Klinikai Onkológiai Társaság; FDA = (Food and Drug Administration) Amerikai Élelmiszer- és Gyógyszer-ellenőrző Hatóság; FLT3 = (Fms-like tyrosine kinase 3) fms-szerú tirozinkináz-3; G-CSF = (granulocyte-colony stimulating factor) granulocytakolónia-stimuláló faktor; GIT $=$ (gastrointestinal tract) gastrointestinalis traktus; GOT = 
(glutamic-oxaloacetic transaminase) glutamin-oxálecetsavtranszamináz; GPT = (glutamic-pyruvic transaminase) glutamin-pirosszőlősav-transzamináz; HERl = (human epidermal growth factor receptor 1) humán epidermalis növekedési faktor receptor-1; HFS = (hand-foot syndrome) kéz-láb szindróma; IFN = interferon; IL-2 = interleukin- 2 IMDC $=($ International Metastatic RCC Database Consortium) Áttétes Vesesejtes Daganatok Nemzetközi Adatbázis Konzorcium; LVEF $=$ (left ventricular ejection fraction) bal kamrai ejekciós frakció; MAPK = (mitogen-activated protein kinase $)$ mitogénaktivált proteinkináz; MCBS $=($ Magnitude of Clinical Benefit Scale) Klinikai Előny Fontossági Skála; MSKCC = $($ Memorial Sloan Kettering Cancer Centre) Sloan Kettering Rákgyógyító Központ; mTOR $=$ (mammalian target of rapamycin $)$ a rapamycin célpontja emlősökben; mTORCl $=($ mammalian target of rapamycin complex 1) a rapamycin célpontja emlősökben komplex 1; NA-ARCCS $=$ (North American Advanced Renal Cell Carcinoma Sorafenib Study) elörehaladott vesesejtes daganatok sorafenibbel végzett észak-amerikai vizsgálata; NCCN $=$ (National Comprehensive Cancer Network) Nemzeti Átfogó Rákbetegségeket Felügyelő Hálózat; NEAK = (Tasks of the National Health Insurance Fund of Hungary) Nemzeti Egészségbiztosítási Alapkezelő; ORR = (overall response rate) teljes válaszadási ráta; $\mathrm{OS}=$ (overall survival) teljes túlélés; PD- $1=($ programmed cell death protein 1$)$ programozott sejthalál protein-1; PDGFR = (platelet-derivated growth factor receptor) thrombocytaeredetű növekedési faktor receptor; PD$\mathrm{Ll}=$ (programmed death-ligand-1) programozott sejthalál ligand-1; PFS $=($ progression-free survival $)$ progressziómentes túlélés; PI3K/Akt = (phosphatidylinositol 3-kinase $/$ serinethreonine kinase) foszfatidilinozitol 3-kináz/szerin-treonin kináz; PISCES $=($ Patient Preference Study of Pazopanib Versus Sunitinib in Advanced or Metastatic Kidney Cancer) a pazopanibnak a sunitinibbel szemben végzett betegpreferenciavizsgálata előrehaladott vagy áttétes vesedaganatban; $\mathrm{RAF}=$ (proto-oncogene serine/threonine-protein kinase) protoonkogén szerin/treonin-protein kináz; RCC $=$ (renal cell carcinoma) vesesejtes daganat; RFT $=$ (regulator of fibroblast growth factor 2 transcription) fibroblast növekedési faktor 2 transzkripció szabályzó; SCF = (stem cell factor) őssejtfaktor; TARGET $=($ Treatment Approaches in Renal Cancer Global Evaluation Trial) vesesejtes daganatok kezelésének globális értékelése; TKI = (tyrosine kinase inhibitor) tirozinkináz-gátló; $\mathrm{TSH}=$ (thyroid-stimulating hormone) pajzsmirigy-stimuláló hormon; $\mathrm{UH}=$ ultrahang; $\mathrm{VEGF}=$ (vascular endothelial growth factor) vascularis endothelialis növekedési faktor; VEGFR $=$ (vascular endothelial growth factor receptor $)$ vascularis endothelialis növekedési faktor receptor; VHL $=$ (von Hippel-Lindau syndrome) von Hippel-Lindau-betegség; $\mathrm{VTE}=($ venous thromboembolism $)$ vénás thromboembolia

A vese daganatai a felnőttkori tumorok között 3-5\%-os gyakorisággal fordulnak elö, a férfiaknál a daganatos megbetegedések között a hetedik, a nőknél a tizedik helyen állnak. Az incidencia közel 20 éven keresztül növekvő tendenciát mutatott, de az utóbbi néhány évben a növekedés leállt, ső́t minimális mértékben csökkent [1].

A vesedaganatok mintegy $90 \%$-a vesesejtes daganat (RCC). Ezen belül a világos sejtes (clear cell) típus ará- nya közel $80 \%$. Az egyéb hisztológiai típusok (papillaris, kromofób, Bellini, egyéb) aránya jóval kisebb [2].

Az etiológiában szerepet játszhatnak külső expozíciók - aktív és a passzív dohányzás, egyes vegyi anyagok (például triklór-etilén). A vesesejtes carcinomák rizikófaktora a magas vérnyomás és az elhízás. A betegség gyakrabban jelenik meg végstádiumú veseelégtelenségben, renalis cisztikus betegségben, valamint sclerosis tuberosa esetén. Dializált és vesetranszplantált páciensek körében ugyancsak gyakoribb [3]. Az RCC 2-3\%-a öröklődő, több autoszomális dominánsan öröklődő szindróma került leírásra, ezek közül a von Hippel-Lindau-betegség (VHL) a leggyakoribb.

A vesedaganat jelentős része tünetmentes marad egészen a betegség késői szakaszáig. Jelenleg a vesesejtes daganatok több mint 50\%-a mellékleletként (véletlenszerüen) kerül felismerésre más, nem specifikus tünetek és egyéb hasi betegségek miatt végzett különböző, nem invazív képalkotó vizsgálat során. A klasszikus triász, a deréktáji fájdalom, a makroszkópos haematuria és tapintható hasi terime hármasa már relatíve ritka. Ennek ellenére különböző paraneoplasiás tünetek (hypercalcaemia, emelkedett vörösvérsejtszám, ismeretlen eredetú láz, Stauffer-szindróma) viszonylag gyakoriak [4].

A betegség prognózisát meghatározza többek között a szövettani típus, a nukleáris gradus, a TNM-beosztás, az általános állapot (Karnowsky-score), a diagnózistól a kezelésig eltelt idő és bizonyos laborparaméterek. Ezek figyelembevételével több prognosztikai beosztás készült - Memorial Sloan Kettering Cancer Centre (MSKCC) és International Metastatic RCC Database Consortium (IMDC) - és került be a terápiás gyakorlatba [4].

\section{Célzott (targeted) terápiák}

Az utóbbi évtizedben a vesesejtes daganatok kezelésében bevezetésre került célzott terápiák áttörést jelentettek a korábbi gyakorlathoz képest. E célzott daganatellenes készítmények mind hatékonyságban, mind tolerálhatóság szempontjából felülmúlták a korábbi immunterápiák (interferon, interleukin) hasonló mutatóit.

\section{A célzott terápiák lehetséges hatásmechanizmusai}

\section{Angiogenezist gátló modalitások}

A vascular endothelial growth factor (VEGF) jelátvivő út blokkolására kétféle lehetőség van:

1. Bizonyos monoklonális antitestek nagy affinitással kötődnek az oldékony VEGF-hez, megakadályozva, hogy kötődjön a receptorán. Így fejti ki a hatását a bevacizumab (Avastin) [5].

2. Gátlást alkalmazhatunk többszörös célpontú tirozinkináz-inhibitorokkal (TKI), amelyek a VEGF-receptor intracelluláris doménjét gátolják. Ebbe a csoporba 
tartozik többek között a sorafenib (Nexavar), a sunitinib (Sutent), a pazopanib (Votrient) és az axitinib (Inlyta) [5].

A tivozanib sokat ígérő, szelektíven ható TKI, amely valamennyi VEGF-receptorra hat pikomoláris koncentrációban. Miután egyéb célpontokon csak nagyobb mennyiségben hat, mellékhatásprofilja kedvezőbbnek tünik. Regisztrációs vizsgálatnak szánt fázis III vizsgálata (TIVO-1) során a teljes túlélés (OS) nem bizonyult szignifikánsan hosszabbnak a sorafenibághoz képest második vonalban, ezért az FDA-törzskönyvet nem kapta meg [6]. A cabozantinib (Cometriq) új tirozinkináz-gátló készítmény, amely a VEGFR- és c-MET-útvonalon fejti ki a hatását, alacsony koncentrációban. A lenvatinib (Lenvima) ugyancsak egy új tirozinkináz-gátló készítmény. Hatását a vascular endothelial growth factor receptor (VEGFR) -1, -2 és -3, a fibroblast growth factor receptor (FGRF) -1, -2, -3 és -4, a platelet-derivated growth factor receptor alpha (PDGFR- $\alpha$ ), a c-KIT és RET protoonkogén gátlásán keresztül fejti ki [5].

\section{Az mTOR- (mammalian target of rapamycin complex I kináz) gátlók}

Az mTOR jelátvivő útnak fontos szerepe van a daganatok növekedésében. A rapamycin az FKBPl2 fehérjével komplexet alkotva gátolja az mTOR múködését. Jelenleg két gyógyszer áll rendelkezésre a vesedaganatok kezelésében, a temsirolimus (Torisel) és az everolimus (Afinitor) [5].

\section{Egyéb támadáspontú gyógyszerek}

Az epidermalis növekedési faktort (EGFR/HERl) célzó gyógyszerek közül sem az anti-EGFR-antitestek (cetuximab és panitumumab), sem a kinázgátlók (gefinitib és erlotinib) nem mutattak számottevő klinikai aktivitást vesedaganatokon, ellentétben más daganattípusokkal (tüdő- és vastagbéltumorok). Ennek ellenére, a nemzetközi guideline-ok közül az NCCN-irányelvbe az erlotinib (Tarceva) bekerült off-label indikációban, nem világos sejtes, IV. stádiumú vesedaganat első vonalbeli kezelésében [7].

\section{Ellenörzöpont-gátló (checkpoint inbibitor) készitmények}

A checkpoint inhibitor készítmények közül egy, a nivolumab (Opdivo) került Európában törzskönyvezésre, vesesejtes daganat indikációban. A közeljövő terápiás reménységeit jelenthetik azok az új terápiás készítmények, amelyek közül több már regisztrálásra került egyéb terápiás indikációkban. A citotoxicus T-lymphocytával társult négy antigén (CTLA-4) blokkolása ipilimumabbal (Yervoy) javított az áttétes melanoma túlélésén, de jelentős autoimmun vagy gyulladásos mellékhatások árán.
A BMS-936558 (nivolumab) és BMS-936559 három különböző daganatos sejtvonalon is hatékonyságot mutatott. A terápia lényege, hogy a nivolumab, amely egy monoklonális antitest, semlegesíti a programozott sejthalált (PD-1) és a társult partner fehérjét (PD-L1). A PD-1 receptor és a PD-L1 ligand összekapcsolódása immunológiai vonatkozásban negatívan hat a T-sejtek müködésére, gátolja az immunkompetens sejtek tumorfelismerő képességét, a tumor kilökődését. A PD-1-gátló nivolumab a vesesejtes daganatokon kívül melanoma malignum és laphámsejtes, nem kissejtes tüdődaganat indikációkban is már terápiás alkalmazásba került. Ebbe a hatástani csoportba tartozik a pembrolizumab (Keytruda) és a tremelimumab. A PD-Ll (programozott sejthalál receptor-1 ligand) gátlók közé tartozik az atezolizumab (Tecentriq), avelumab (Bavencio) és a durvalumab [5].

\section{A klinikai gyakorlatba bekerült célzott terápiás készítmények}

1. A bevacizumab (Avastin) egy iv. alkalmazott rekombináns humán monoklonális antitest, amely a keringő VEGF-proteint közömbösíti. Szokásos dózisa $10 \mathrm{mg} /$ ttkg kéthetente. Interferonnal kombinálva, az interferon-monoterápiával szemben, két klinikai vizsgálat (AVOREN és a CALGB 90206) is összehasonlította. A vizsgálatokba 649, illetve 732 beteg került bevonásra. Mindkét vizsgálatban előny mutatkozott a kombinációs kezelés részéról a progressziómentes túlélés (PFS) (10,2 vs. 5,4 , illetve 8,5 vs. 5,2 hónap) és az OS (23,3 vs. 21,3 , illetve 18,3 vs. 17,4 hónap) vonatkozásában. Az AVOREN trialben a kombinációs kezelés objektív válaszadási rátája (ORR) 31 vs. 13, a CALGB 90206 trialben 25,5 vs. $13,1 \%$ volt. A kombinációs kezelés mellékhatásprofilja kedvezőtlenebb volt, mint bármelyik komponens monoterápia formájában $[8,9]$.

2. A sorafenib (Nexavar) orális multikináz-inhibitor, számos receptor-tirozinkinázon hat (VEGFRl-3, PDGF-R- $\beta$, FLT3 és c-KIT). A sorafenib a MAPK-útvonal kulcsfehérjéjének, a RAF-nak az egyedüli gátlószere is. A MAPK-szignálok alapvetőek a sejtproliferációban, és fokozott aktivitást mutatnak tumorokban. Dózisa $2 \times$ $400 \mathrm{mg}$ per os/nap. A sorafenib hatását először a Treatment Approaches in Renal Cancer Global Evaluation Trial (TARGET) vizsgálatban értékelték. Citokinkezelésre refrakter, összesen 903 beteget randomizáltak aktív vs. placebokarra. A sorafenibkezelés különösen a PFSben hozott jelentős javulást, 5,5 vs. 2,8 hónap. Az OS tekintetében az előny, a végső analízis szerint, 17,8 vs. 14,3 hónap volt [10].

3. A sunitinib (Sutent) VEGFRl-3, PDGFR, KIT, RET és FLT3 tirozinkináz-gátló, orálisan szedhető készítmény. Szokásos dózisa $50 \mathrm{mg} /$ nap 28 napig szedve, amelyet 14 napos terápiás szünet követ. A törzskönyvezését megelőző fázis III vizsgálatba 750 , világos sejtes daganatos beteg került bevonásra, akik a gyógyszert első 
vonalban kapták, az egyik ágon sunitinibet, a másik ágon interferont $(3 \times 9 \mathrm{ME} /$ hét $)$. Az elsődleges végpont ezúttal a PFS, a másodlagos végpontok az ORR és az OS voltak. A sunitinib minden végpontban szignifikáns előnyt eredményezett az interferonághoz képest. PFS: 11 vs. 5 hónap; ORR: $47 \%$ vs. 12\%; OS: 26,4 vs. 21,8 hónap [11].

4. A pazopanib (Votrient) orálisan alkalmazható multitirozinkináz-inhibitor, amely a VEGFRl-3, a PDGFR- $\alpha$ és - $\beta$, valamint a c-KIT hatásos gátlószere. Napi dózisa 2 $\times 400 \mathrm{mg}$. Engedélyezéséhez vezető fázis III, kettős vak, placebokontrollált vizsgálatba (VEG105192) 435 beteget vontak be, 2:1 arányban randomizálva, az aktív ág előnyére. A pazopanib előnye a PFS vonatkozásában (9,2 vs. 4,2 hónap) markánsan jelentkezett. Az OS medián értéke 22,9 hónap volt a pazopanib- és 20,5 hónap a placebokaron. Az ORR az aktív karon 30\% volt, a placeboág 3\%-ához képest $[12,13]$. A COMPARZ fázis III klinikai vizsgálatba 1110 , terápianaiv beteget vontak be, 1:1 arányban radomizálva, pazopanib- vs. sunitinibkarra. Az elsődleges végpont a PFS, a másodlagos végpontok az OS, a biztonságosság és az életminőség voltak. Öszszességében a vizsgálat célja annak bizonyítása volt, miszerint a pazopanib hatásossága nem kisebb, mint a korábbiakban alkalmazott sunitinib. A PFS 8,4 vs. 9,5 hónap, az OS 28,4 vs. 29,3 hónap, az ORR 31 vs. 25\% lett, azaz nem volt szignifikáns különbség a két ág között. A biztonságosság és az életminőség tekintetében a pazopanibkaron mutatkozott előny [14].

5. Az axitinib (Inlyta) orálisan alkalmazható, második generációs készítmény. A VEGF 1, 2 és 3-as receptorain ható TKI. Az axitinibdózis $2 \times 5 \mathrm{mg} /$ nap per os. Fázis III regisztrációs vizsgálatában (AXIS) az axininib és a sorafenib összehasonlítását végezték második vonalbeli elrendezésben. 723 beteg adatai alapján a terápiásválaszarány 19 vs. 9\%, a medián PFS 6,7 vs. 4,7 hónap volt az axitinib javára. Az átlagos túlélés is az axitinibkaron volt hosszabb, 20,1 vs. 19,2 hónap. A citokinrefrakter betegcsoportban PFS-elöny az axitinibkaron 12,1 vs. 6,5 hónap, a suntinibágon 4,8 vs. 3,4 hónap volt [15].

6. A cabozantinib (Cometriq) egy új tirozinkináz-gátló készítmény, amely a VEGFR- és c-MET-útvonalon fejti ki a hatását, alacsony koncentrációban. Gátolja a TKI-kezelések során a MET és AXL jelátviteli utakon keresztül kialakuló szekunder rezisztenciát és hatékonynak bizonyult csontáttétek ellen is. Vesedaganat és medullaris pajzsmirigydaganat indikációban mind Európában, mind az Egyesült Államokban törzskönyvezésre került. Multicentrikus, fázis III vizsgálatának (METEOR) eredményeit a 2015. évi ESMO-kongresszuson prezentálták. Második vonalbeli alkalmazásban, 658 beteg bevonásával, a cabozantinib hatását vizsgálták everolimusszal szemben. A PFS 7,4 hónap volt a cabozantinibkaron az everolimus 3,8 hónapjával szemben. A klinikai hatékonyság szempontjából az arány még kedvezőbb volt, $21 \%$ vs. $5 \%$. Az OS tekintetében az előny a cabozantinib javára 21,4 vs. 16,5 hónap lett $[16,17]$.
7. A lenvatinib (Lenvima) ugyancsak egy új tirozinkináz-gátló készítmény. Hatását a vascular endothelial growth factor receptor (VEGFR) -1, -2 és -3, a fibroblast growth factor receptor (FGRF-1, -2, -3 és -4), a platelet-derivated growth factor receptor alpha (PDGFR- $\alpha$ ), a c-KIT és RET proto-oncogene gátlásán keresztül fejti ki. Mind a Food and Drug Administration (FDA), mind a European Medicines Agency (EMA) befogadta a készítményt vesedaganat és pajzsmirigydaganatok különböző típusainak indikációjában. Multicentrikus, fázis II vizsgálatának (HOPE) eredményei alapján került regisztrációra. Második vonalbeli alkalmazásban, 153 beteg bevonásával, a lenvatinib hatását vizsgálták egy háromkarú (lenvatinib vs. lenvatinib + everolimus vs. everolimus) vizsgálatban. A PFS 14,6 hónap volt a kombinációs karon, a lenvatinib-monoterápia 7,4 hónapjával és az everolimus 5,5 hónapjával szemben. Az ORR szempontjából az arány még kedvezóbb volt a kombinációs kezelés javára a lenvatinibbel és az everolimusszal szemben, 43 vs. 27 vs. $6 \%$. A teljes túlélésre vonatkozó adatok: 25,5 vs. 19,1 vs. 15,4 hónap [18].

8. A temsirolimus (Torisel) az mTOR jelátvivő út blokkolásán keresztül fejti ki hatását. Dózisa $25 \mathrm{mg} / \mathrm{m}^{2} /$ hét iv. infúzióban. Elsőként terápiarezisztens, áttétes vesetumoros betegeken vizsgálták. A fázis II vizsgálat retrospektív analízise alapján úgy tünt, hogy az elsősorban a rossz prognosztikai csoportba tartozó betegeknél jár terápiás előnnyel alkalmazása. Fázis III vizsgálata 626, kezeletlen, rossz prognózisú beteg bevonásával történt. A vizsgálat háromkarú volt - temsirolimus vs. interferon vs. temsirolimus + interferon. A temsirolimus előnye mind a PFS-, mind az OS-adatokban megnyilvánult. $\mathrm{Az}$ interferon-monoterápiához képest a PFS 3,8 hónap lett az 1,9 hónaphoz képest, ugyanezek az adatok az OS vonatkozásában 10,9 vs. 7,3 hónap lettek. A kombinációs karon a PFS 3,7 hónap, az OS 8,4 hónap lett, azaz az adatok nem voltak jobbak a temsirolimuskar eredményeihez képest [19].

9. Az everolimus (Afinitor) mTOR-gátló, de orálisan adható készítmény. Az everolimus dózisa $10 \mathrm{mg} / \mathrm{nap}$ per os. A Record-1 (Renal Cell Carcinoma Oral RAD001) fázis III vizsgálatba olyan 416 beteg került beválasztásra, akik TKI-kezelés kudarca után második vagy harmadik vonalban kapták a kezelést. E kettős vak, randomizált vizsgálat keretében a betegek 2:1 arányban kaptak everolimust, illetve placebót. A PFS-adatok szignifikánsan jobbak voltak az aktív karon (4,9 vs. 1,9 hónap), az OS tekintetében a különbség kisebb volt, 14,8 vs. 14,4 hónap [20].

10. A nivolumab (Opdivo) egy teljes mértékben humán immunglobulin $\left(\mathrm{IgG}_{4}\right)$. Dózis: $3 \mathrm{mg} / \mathrm{ttkg}$ iv., kéthetente. Vizsgálatok/eredmények: Az Európai Klinikai Onkológiai Társaság (ESMO) 2015-ös kongresszusán ismertették a CheckMate 025 fázis III vizsgálatnak az eredményeit, amelyben második vonalbeli alkalmazásban, az egyik karon nivolumabot, a másik karon everolimust kaptak a betegek. Az OS 25 vs. 19,6 hónap volt a 
nivolumab javára. Az ORR (25\% vs. 5\%) és a PFS (4,6 vs. 4,4 hónap) tekintetében is előnyt mutatott az Opdivo. Kevesebb grade 3-4-es fokozatú mellékhatás fordult elő a nivolumabcsoportban, az életminőség is egyértelmúen kedvezóbb volt. A PD-Ll-expresszió volt nem prediktív a hatékonyságra [21]. Mivel második vonalban effektívnek bizonyult, jelenleg első vonalban folynak a klinikai vizsgálatok.

\section{$\mathrm{Az}$ áttétes vagy előrehaladott vesesejtes daganatok első vonalbeli kezelése $[4,22]$}

\section{(1. és 2. ábra)}

$\mathrm{Az}$ intenzíven folyó gyógyszer kutatás/fejlesztés eredményeként 2012 (az axitinib törzskönyvezése), azaz három év szünet után, 2015 és 2016 folyamán három új készítmény hatósági regisztrációja történt meg, amelyek változást hoztak, igaz, egyelőre nem első vonalbeli alkalmazásban, a vesesejtes daganatok kezelési stratégiájában.

\section{Nem világos sejtes daganatok}

A nem világos sejtes daganatok kezelésében l-es típusú National Comprehensive Cancer Network (NCCN) -ajánlással csak a temsirolimus rendelkezik a rossz prognózis esetén, 2A típusú ajánlással a többi prognosztikai csoportba tartozó betegek vonatkozásában.

További lehetôségként, az NCCN és European Society for Medical Oncology (ESMO) -ajánlás szerint, elsősorban a sunitinib (ESMO II, B) ajánlott. További lehetőségként az NCCN-irányelv szerint szóba jöhet az axitinib, a bevacizumab, a cabozantinib, az erlotinib, az everolimus, a lenvatinib + everolimus, a nivolumab, a pazopanib, a sorafenib, illetve a best supportive care (BSC) alkalmazása is. Az ESMO-irányelv szerint III, B fokozatú ajánlással bír a temsirolimus, a sorafenib, a pazopanib és az everolimus.

Az NCCN-irányelv külön ajánlást tartalmaz a kemoterápiás kezelést illetően. Dominánsan sarcomatoid típusú daganat esetén gemcitabin + doxorubicin (2B) vagy gemcitabin + sunitinib (2B) kezelés adható. Gyüjtőcsatorna (Bellini) vagy medullaris daganat esetén carbopla-

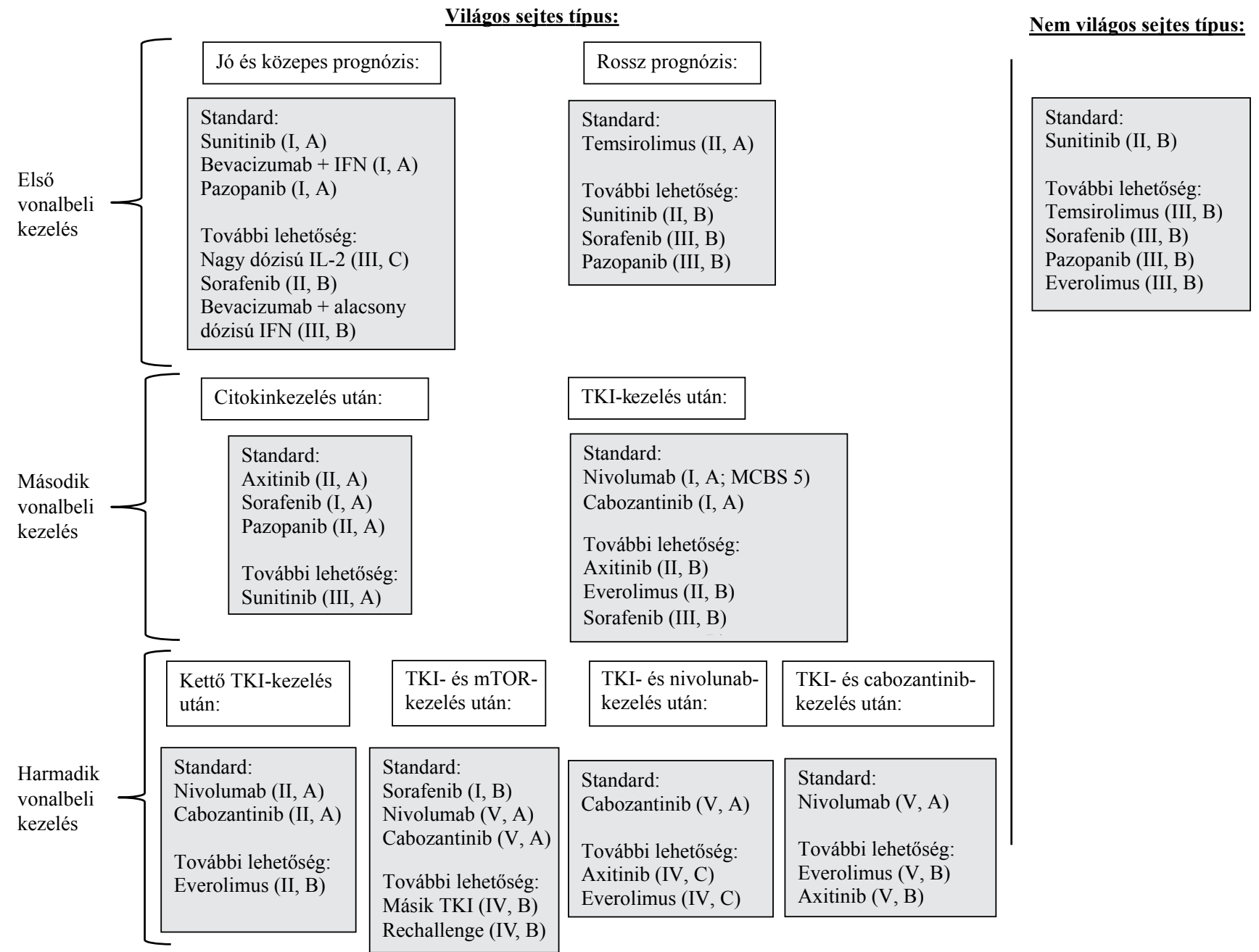

1. ábra |Az áttétes vagy előrehaladott vesesejtes daganatok kezelésére vonatkozó európai (ESMO-) ajánlás 


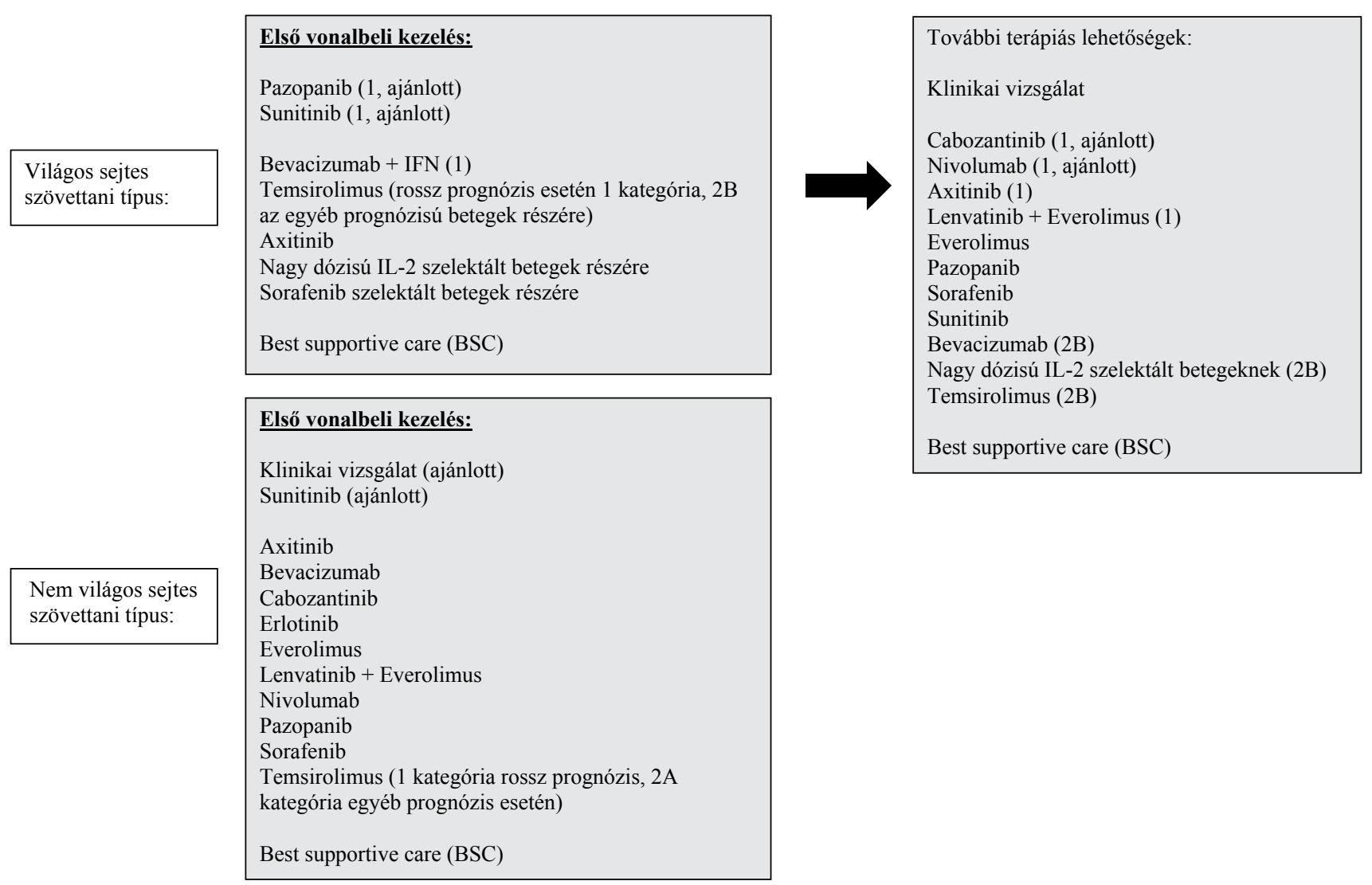

2. ábra |Az áttétes vagy előrehaladott vesesejtes daganatok kezelésére vonatkozó amerikai egyesült államokbeli (NCCN-) ajánlás

tin + gemcitabin + paclitaxel vagy cisplatin + gemcitabin kombináció adása javasolt.

Tekintettel a szerény vizsgálati eredményekre, ebben a betegségcsoportban további vizsgálatok szükségesek, azaz a betegek klinikai kutatásokba való bevonása lenne előnyös.

\section{Világos sejtes vagy dominánsan világos sejtes daganatok}

\section{Első vonalbeli kezelés}

Első vonalban számos kezelés alkalmazható a nemzetközi ajánlások szerint. NCCN l-es, illetve jó és közepes prognosztikai kategória esetén ESMO I, A típusú ajánlással adható sunitinib, pazopanib, a bevacizumab + inferferon, rossz prognosztikai csoportban a temsirolimus (NCCN l és ESMO II, A), ezen utóbbi szer 2B NCCNajánlással bír jó és közepes prognózis esetén.

A NCCN-irányelv további lehetőségként klinikai gyógyszervizsgálatot, axitinibet, BSC-t és válogatott betegcsoportban sorafenib és nagy dózisú interleukin (IL2 ) adását javasolja.

Az ESMO-irányelv egyéb opcióként, jó és közepes prognózis esetén nagy dózisú IL-2 (III, C), sorafenib (II, B) vagy bevacizumab + alacsony dózisú IFN (III, B) adását, rossz prognosztikai kategória esetén sunitinib (II, B), sorafenib (III, B) vagy pazopanib (III, B) alkalmazását javasolja.

\section{Második vonalbeli kezelés}

Második vonalbeli kezelés tervezésekor nem elhanyagolható szempont az első vonalbeli kezelés jellegének figyelembevétele.

Első vonalban alkalmazott TKI szedését követő lehetőségek: nivolumab (ESMO I, A, illetve NCCN 1), cabozantinib (I, A, illetve I), everolimus + lenvatinib (NCCN 1), axitinib (II, B, illetve 1 ), everolimus (II, B), sorafenib (III, B).

Az ESMO bevezette a klinikai elóny fontosság fokozat fogalmát - Magnitude of Clinical Benefit Scale (MCBS). A nivolumab és cabozantinib regisztrációjához vezető fázis III klinikai vizsgálatok az everolimusszal szemben jelentős OS- és ORR- (a cabozantinib esetében PFS is) előnyt mutattak. A betegek a kezelést másodvonalban, egy vagy két TKI-kezelés után kapták. Miután mindkét szer hozzáférhetősége limitált, az ESMO-irányelv szerint, amennyiben csak a nivolumab elérhető, az ajánlási szint I, az MCBS score 5 . Ha a nivolumab és a cabozantinib elérhetősége egyaránt biztosított, mindkét gyógyszer ajánlott, az ESMO-MCBS score 5 a nivolumab, 3 a cabozantinib esetében (1. táblázat). 
1. táblázat | ESMO MCBS. Kiegészítés az ESMO-irányelvhez (2017. 04. 10.)

\begin{tabular}{|c|c|c|c|c|c|c|c|}
\hline Terápia & Indikáció & $\begin{array}{l}\text { Regisztrációs } \\
\text { vizsgálat }\end{array}$ & Kontrollkar & Túlélési előny & $\begin{array}{l}\text { HR } \\
(95 \% \mathrm{Cl})\end{array}$ & $\begin{array}{l}\text { Életminőség / } \\
\text { Mellékhatás }\end{array}$ & $\begin{array}{l}\text { MCBS } \\
\text { score }\end{array}$ \\
\hline $\begin{array}{l}\text { Nivolumab } \\
\text { (PD-1 } \\
\text { checkpoint } \\
\text { inhibitor) }\end{array}$ & $\begin{array}{l}\text { Elörehaladott } \\
\text { világos sejtes } \\
\text { daganat, egy } \\
\text { vagy két } \\
\text { VEGF-gátló } \\
\text { kezelés után }\end{array}$ & $\begin{array}{l}\text { Study of } \\
\text { Nivolumab vs. } \\
\text { Everolimus in } \\
\text { Pre-Treated } \\
\text { Advanced or } \\
\text { Metastatic } \\
\text { Clear-Cell } \\
\text { Renal Cell } \\
\text { Carcinoma } \\
\text { (CheckMate } \\
\text { 025) [21] } \\
\text { Phase III }\end{array}$ & $\begin{array}{l}\text { Everolimus } \\
\text { Medián OS: } \\
\text { 19,6 hónap }\end{array}$ & $\begin{array}{l}\text { OS-előny: } \\
5,4 \text { hónap }\end{array}$ & $\begin{array}{l}\text { OS HR: } 0,73 \\
(0,57-0,93)\end{array}$ & $\begin{array}{l}\text { Jobb } \\
\text { mellékhatás- } \\
\text { profil és } \\
\text { életminőség }\end{array}$ & $5($ Form $2 a)$ \\
\hline Cabozantinib & $\begin{array}{l}\text { Felnőttek } \\
\text { elörehaladott } \\
\text { vesesejtes } \\
\text { daganata, } \\
\text { VEGFR } \\
\text { tirozinkináz- } \\
\text { gátló után }\end{array}$ & $\begin{array}{l}\text { A Study of } \\
\text { Cabozantinib } \\
\text { (XL184) vs } \\
\text { Everolimus in } \\
\text { Subjects with } \\
\text { Metastatic } \\
\text { Renal Cell } \\
\text { Carcinoma } \\
\text { (METEOR) } \\
\text { [17] } \\
\text { Phase III }\end{array}$ & $\begin{array}{l}\text { Everolimus } \\
\text { Medián OS: } \\
\text { 16,5 hónap }\end{array}$ & $\begin{array}{l}\text { OS-előny: } \\
\text { 4,9 hónap }\end{array}$ & $\begin{array}{l}\text { OS HR: } 0,66 \\
(0,53-0,83)\end{array}$ & - & $3($ Form $2 \mathrm{a})$ \\
\hline $\begin{array}{l}\text { Lenvatinib + } \\
\text { Everolimus }\end{array}$ & $\begin{array}{l}\text { Egy VEGF- } \\
\text { gátló kezelés } \\
\text { után }\end{array}$ & $\begin{array}{l}\text { Lenvatinib, } \\
\text { Everolimus, and } \\
\text { the } \\
\text { Combination in } \\
\text { Patients with } \\
\text { Metastatic } \\
\text { Renal Cell } \\
\text { Carcinoma: } \\
\text { A Randomised, } \\
\text { Phase 2, } \\
\text { Open-Label, } \\
\text { Multicentre } \\
\text { Trial [18] } \\
\text { Phase II }\end{array}$ & $\begin{array}{l}\text { Everolimus } \\
\text { Medián OS: } \\
\text { 15,4 hónap }\end{array}$ & $\begin{array}{l}\text { OS-előny: } \\
\text { 10,1 hónap }\end{array}$ & $\begin{array}{l}\text { OS HR: } 0,51 \\
(0,30-0,88)\end{array}$ & - & $\begin{array}{l}4 \text { (Form 2a; } \\
\text { az OS csak } \\
\text { másodlagos } \\
\text { végpont volt, } \\
\text { kis, fázis II } \\
\text { vizsgálat) }\end{array}$ \\
\hline
\end{tabular}

Az NCCN-irányelv szerint további lehetséges alternatíva lehet a sunitinib, a pazopanib, a temsirolimus (2B), a bevacizumab (2B), a nagy dózisú $I L-2$, a klinikai vizsgálat és a BSC.

Amennyiben a beteg első vonalban alkalmazott citokinkezelés mellet progrediált, második vonalban, az ESMO-irányelv szerint, sorafenib (I, A), axitinib (II, A) és pazopanib (II, A) adható. Helye lehet a sunitinib(III, A) terápiának is.

Az NCCN-irányelv szerint további lehetséges alternatíva lehet itt is a temsirolimus (2B), a bevacizumab (2B), a nagy dózisú $I L-2$, a klinikai vizsgálatban való részvétel és a BSC.

\section{Harmadik vonalbeli kezelés}

Harmadik vonalbeli ajánlással egyedül az ESMO-irányelv rendelkezik.
Két korábbi TKI-kezelés után elsősorban nivolumab (II, A), cabozantinib (II, A), esetleg everolimus (II, B) adása javasolt, TKI-mTOR gátló szekvenciát követően sorafenib (I, B), nivolumab (V, A), cabozantinib (V, A) adása indokolt, illetve korábban nem alkalmazott TKI adása (IV, B) vagy TKI-rechallenge (IV, B) jöhet szóba.

Előzetes TKI-nivolumab szekvencia után elsősorban cabozantinib (V, A), alternatívaként axitinib (IV, C) vagy everolimus $(\mathrm{IV}, \mathrm{C})$ választandó.

Megelőző TKI-cabozantinib szekvencia után elsősorban nivolumab (V, A) esetleg axitinib (V, B) vagy everolimus $(\mathrm{V}, \mathrm{B})$ ajánlott.

\section{Összefoglalva}

Első vonalban, rossz prognózis esetén a standard kezelés a temsirolimus, jó és közepes prognózis esetén sunitinib vagy pazopanib adható [5]. E két szer között lényeges 
hatásbeli különbség nincs, ezt a COMPARZ vizsgálat igazolta [14]. A PISCES study szintén e két szer összehasonlító vizsgálata volt (pazopanib vs. sunitinib szekvencia), de az elsődleges végpont a tolerálhatóság és a betegek preferenciája volt. A betegek választása az életminőség szempontjából egyértelműen a pazopanibra esett [23]. Nyilván a betegek kísérő betegségei is determinálják a választást - például szívelégtelenség esetén sunitinib, májbetegség esetén pazopanib adása nem javasolt. További lehetőségként bevacizumab + IFN vagy szelektált betegek részére $I L-2$ adható [5].

Második vonalban cabozantinib vagy nivolumab adása jön szóba. A két gyógyszer hatása között egyértelmű különbség nincs. A regisztrációs vizsgálatok adatai szerint rossz prognózis, tünetes betegség vagy nagy tumortömeg esetén inkább a cabozantinib, jó vagy közepes prognózis esetén inkább nivolumab adása indokolt. Az adatok nem egyértelmúek, mind a METEOR, mind a CheckMate 025 trial alcsoport-analízise magas kockázatú betegek részére a cabozantinibet, illetve a nivolumabot ajánlja [5].

Javasolt további terápiás szekvenciaként lenvatinib + everolimus, utána axitinib, majd sorafenib, ezt követően bevacizumab adása jöhet szóba [5].

\section{A célzott kezelések hazai gyakorlata (2. táblázat)}

Magyarországon a célzott terápiás kezelések, csak és kizárólag, döntően világos sejtes daganatok esetében finanszírozottak. Emiatt, sajnálatos módon, a nem világos sejtes daganatok csoportjába tartozó, igaz, nem túl nagy létszámú betegpopuláció számára csak a citokin- (interferon-) kezelés, illetve a szupportív ellátás elérhető, bár papillaris tumorok esetén sunitinibkezelés a Nemzeti Egészségbiztosítási Alapkezelőtől (NEAK) egyedi méltányossági kérelem (EMK) beadásával igényelhető.

A világos vagy dominánsan világos sejt típusba tartozó betegek számára a célzott kezelések eszköztárának szinte minden eleme térítésmentesen rendelkezésre áll, bár nyilván anyagi megfontolások miatt a magyarországi finanszírozási protokoll nem áll teljes összhangban a nemzetközi ajánlásokkal. Ez elsősorban a kezelési vonalak számának limitálásában és az alkalmazott készítmények szekvenálási szabadságának korlátozásában nyilvánul meg.

A jelenlegi gyakorlat szerint jó és közepes prognózis esetén első vonalban sunitinib-, pazopanib-vagy citokin- kezelés adható. A rossz prognosztikai csoportba tartozó betegek részére első vonalban temsirolimus- vagy citokinkezelés kezdhető.

Második vonalban a rossz prognózisú betegek számára rendelkezésre álló, finanszírozott protokoll nincs. A jó és közepes prognózisú csoportba tartozó betegek részére, második vonalban, sunitinibkezelés után axitinib vagy everolimus adható, pazopanibkúrát követően kizárólag everolimus rendelhető. Azon betegek részére, akik első vonalban citokinkezelést kaptak, második vonalban sunitinib, pazopanib, axitinib és sorafenib egyaránt finanszírozott.

Az első vonalban a bevacizumab, másodvonalban a cabozantinib, a lenvatinib és a nivolumab alkalmazása hazánkban jelenleg (még?) nem támogatott.

Miután a nivolumab Európában is törzskönyvezésre került, jó és közepes prognózisú, döntően világos sejtes vesedaganatban szenvedő betegek részére, második vonalban, NEAK-EMK útján igényelhető, bár az engedélyezés meglehetősen hektikus és nem következetes.

Harmadik vagy többedik vonalban finanszírozott terápia nincs [24]. Kezelés csak esetlegesen, egyedi méltányosság alapján vagy saját erőből érhető el, bár már TKIrechallenge NEAK-engedélyére is volt már precedens.

\section{A célzott terápiák mellékhatásai}

\section{Bevacizumab + interferon (IFN)}

Bár hazánkban ez a kezelés semmilyen indikációban nem finanszírozott, de a nemzetközi ajánlásokban magas evidenciaszinttel szerepel.

Az AVOREN study eredményeinek alapján megállapítható volt, hogy a bevacizumab hozzáadása az interferonhoz, az interferon-monoterápiához képest, jelentősen emelte azoknak a mellékhatásoknak az előfordulási gyakoriságát, amelyek a VEGF-gátláshoz voltak köthetôk. Ezek a magas vérnyomás (26\% vs. $9 \%$ ), a proteinuria ( $18 \%$ vs. $3 \%$ ) és a vérzéses események (33\% vs. $9 \%)$ voltak. Grade 3-4 hypertensio és fehérjevizelés 6, illetve 8\%-ban fordultak elő. Artériás thromboemboliás (ATE) események, gastrointestinalis perforációk, sebgyógyulási komplikációk és congestiv szívelégtelenség valamennyi, illetve a 3-4-es fokozatú mellékhatások esetén is több mint 1\%-ban történtek. A CALGB vizsgálat is hasonló megállapításokkal zárult. Grade 3-4 magas vérnyomás ( $11 \%$ vs. $0 \%$ ) és fehérjevizelés ( $15 \%$ vs. <1\%) előfordulása szignifikánsan magasabb volt a kombinációs karon. Az

2. táblázat $\mid$ Az áttétes vagy előrehaladott vesesejtes daganatok kezelésére vonatkozó hazai (NEAK) protokoll

\begin{tabular}{|c|c|c|c|c|c|c|c|}
\hline \multicolumn{8}{|c|}{ Prognózis besorolása } \\
\hline \multicolumn{7}{|c|}{ Jó/Közepes } & Rossz \\
\hline \multicolumn{2}{|c|}{ Sutent } & \multicolumn{4}{|c|}{ Roferon-A } & Votrient & \multirow[t]{3}{*}{ Torisel } \\
\hline \multicolumn{2}{|c|}{ Progresszió } & \multicolumn{4}{|c|}{ Progresszió } & Progresszió & \\
\hline Inlyta & Afinitor & Inlyta & Sutent & Votrient & Nexavar & Afinitor & \\
\hline
\end{tabular}


összes, illetve grade 3-4 fokozatú szív infarktus/ischaemia, balkamra-elégtelenség, emésztőtraktus-perforáció előfordulása megközelítette/elérte az 1\%-ot $[8,9]$.

Tekintettel mindezekre a nem kívánt eseményekre, vérző, sebgyógyulási zavarban szenvedő vagy gastrointestinalis perforáción átesett betegek részére a bevacizumab nem javasolható. Sebészeti beavatkozások elvégzése elött és után legalább 28 nap terápiás szünet indokolt. A proteinuria és vérnyomás rendszeres monitorozása is feltétlenül szükséges, fóleg a kontrollálatlan hypertensio okozta szövődmények elkerülése céljából.

\section{Sorafenib}

A regisztrációjához vezető TARGET trial adatai szerint a leggyakoribb mellékhatások a hasmenés (48\%), a fáradékonyság (11\%), a magas vérnyomás (17\%), különböző bőrtünetek: bőr pír/hámlás (41\%), kéz-láb szindróma (33\%), alopecia $(31 \%)$, viszketés (17\%) és bőrpír (13\%) voltak. Grade 3-4 mellékhatások nem voltak gyakoriak, legnagyobb számban a kéz-láb tünetcsoport (6\%) fordult elő. Az ugyanilyen fokozatú hypertensio a betegek 4\%-ánál jelentkezett. Egy 2504 páciens bevonásával végzett nyílt vizsgálat (North American Advanced Renal Cell Carcinoma Sorafenib Study - NA-ARCCS) adatai szerint a leggyakrabban előforduló nem kívánt események a kéz-láb szindróma (18\%), rash (14\%), hypertensio (12\%), fáradékonyság $(11 \%)$, diarrhoea $(8 \%)$ és hányinger $(5 \%)$ voltak $[10,25]$.

A kezeléssel kapcsolatos betegkövetés során elsősorban a bőrtünetek felismerése és ellátása, valamint a többi TKI-terápiához hasonlóan a vérnyomás monitorozása bír kiemelkedő jelentőséggel.

\section{Sunitinib}

Fázis III regisztrációs vizsgálatának adatai alapján a leggyakoribb mellékhatások a hasmenés (61\%), fáradékonyság $(54 \%)$, a hypertensio $(30 \%)$, a stomatitis $(30 \%)$ és a kéz-láb szindróma (29\%) voltak. A leggyakoribb grade 3-4 mellékhatások a magas vérnyomás (12\%), a fáradékonyság (11\%), a hasmenés (9\%) és kéz-láb szindróma (9\%) voltak. Ugyanilyen fokozatú laboreltérések közül a neutropenia, lymphopenia, a lipázemelkedés és hyperuricaemia voltak a leggyakoribbak. Pajzsmirigy-alulmúködés 14\%-ban, a balkamra-elégtelenség 13\%-ban fordult elő. Egy 4564 beteg bevonásával lebonyolított nyílt vizsgálat (Expanded-Access Trial) adatai szerint a leggyakoribb mellékhatások a hasmenés (44\%), fáradékonyság (37\%) voltak, 3-4 fokozatú mellékhatások közül a fáradékonyság $(8 \%)$ és vérlemezkeszám-csökkenés (8\%) emelkedtek ki [11, 26].

Elsősorban a magas vérnyomás magas incidenciája miatt a vérnyomás rendszeres ellenőrzése és szükség esetén kezelése rendkívül fontos sunitinibterápia esetén. Balkamra-elégtelenség, QT-megnyúlás, ritka torsade de pointes $(<0,1 \%)$ előfordulása miatt időszakos kardiális ultrahang- és EKG-vizsgálatok elvégzése ajánlott. A pajzsmirigymúködés monitorozása és hypothyreosis esetén kezelése hasonlóképpen fontos. Az egyéb, életminőséget befolyásoló, nem kívánt esemény jelentkezése esetén azok célirányos ellátása szükséges. Kéz-láb szindróma esetén a bőr hidratálása, kéz- és lábápoló termékek használata és a fájdalomcsillapítás a kezelés alapja.

\section{Pazopanib}

A regisztrációját megelőző fázis III vizsgálat eredménye szerint a hasmenés és hypertensio voltak a leggyakoribb mellékhatások (52\%, illetve 40\%). Vérzéses szövődmények (bármely lokalizációban) a páciensek 13\%-ánál fordultak elő. A laboratóriumi eltérések közül legmagasabb számban a különböző májfunkciós eltérések jelentkeztek, GOT- és GPT-emelkedés egyaránt 53\%-os (grade 3-4 fokozat 12\% és 8\%) gyakorisággal. Hematológiai abnormalitások (leukopenia, neutropenia és thrombocytopenia) körülbelül a betegek egyharmadánál fordultak elő [12].

Pazopanib alkalmazása esetén, a többi TKI-terápiához hasonlóan, a vérnyomás, a pajzsmirigymúködés monitorozása, QT-megnyúlás veszélye miatt az EKG és elektrolit-háztartás ellenőrzése elengedhetetlen. Súlyos és akár fatális hepatotoxicitas miatt a májfunkció szoros követése rendkívül fontos!

Valamennyi TKI-terápia esetén hatályos az a javaslat, hogy az anamnézisben szereplő, hat hónapnál nem régebbi ATE, gastrointestinalis perforáció, emésztőtraktuson belüli vagy cerebralis vérzés esetén a kezelés kerülendő.

\section{Axitinib}

Az axitinibkezelés kapcsán előforduló mellékhatások jelentkezése a korábbi generációs TKI-szerekhez hasonló. Regisztrációs fázis III vizsgálata kapcsán észlelt nemkívánatos események közül a leggyakoribbak a hasmenés $(55 \%)$, a magas vérnyomás $(40 \%)$, fáradékonyság (39\%), hányinger (32\%) pajzsmirigy-alulmúködés (19\%) voltak. Grade 3-4 mellékhatások közül a hasmenés aránya megelőző sunitinibkezelés esetén 13,7\%, korábbi citokinkezelést követően 9,5\% volt. Magas vérnyomás esetén az arány 10,5 vs. $25,4 \%$, fáradékonyság esetén 9,5 vs. $12,7 \%$ és kéz-láb szindróma esetén 5,8 vs. $4,8 \%$ volt. A sunitinibterápia okozta hematológiai eltérésekkel ellentétben az axitinib neutropeniát és thrombocytopeniát ritkán okoz [15].

Az axitinibterápiával kapcsolatos teendők megegyezőek az első generációs TKI-kezelések kapcsán leírtakkal.

\section{Cabozantinib}

A cabozantinibkezelés okozta mellékhatások hasonlatosak a korábbi TKI-készítmények okozta nemkívánatos eseményekhez. A regisztrációs METEOR studyban a 
leggyakoribb mellékhatások a hasmenés (74\%), a fáradékonyság $(56 \%)$, hányinger $(50 \%)$, kéz-láb szindróma $(42 \%)$, hypertonia $(37 \%)$, pajzsmirigy-alulmúködés (20\%) és a mucositis (19\%) voltak.

A laborvizsgálati eltérések közül a májfunkciós értékek emelkedése (18\%), a vérszegénység (17\%) és a proteinuria $(12 \%)$ emelhetők ki.

Grade 3-4 fokozatú mellékhatások közül a magas vérnyomás (15\%) és a diarrhoea (11\%) voltak a leggyakoribbak $[16,17]$.

\section{Lenvatinib}

A lenvatinib okozta mellékhatások is TKI-tipikusak. A regisztrációs fázis II vizsgálatban, a kombinációs kar (lenvatinib + everolimus) okozta leggyakoribb mellékhatások, az everolimuskarhoz képest, a következők voltak: hasmenés (81 vs. 34\%), fáradékonyság (73 vs. 40\%), arthralgia/myalgia (55 vs. 32\%), hányás/hányinger ( $48 / 45$ vs. $12 / 16 \%)$, stomatitis ( 44 vs. $50 \%$ ), hypertonia (42 vs. $10 \%$ ), perifériás oedema (42 vs. $20 \%$ ).

A leggyakrabban előforduló grade 3-4 mellékhatások közül a hasmenés (19 vs. 2\%), a fáradékonyság (18 vs. $2 \%$ ), a magas vérnyomás ( 13 vs. $2 \%$ ) és a veseelégtelenség ( 10 vs. $2 \%$ ) emelhető ki. Grade 3-4 laboratóriumi eltérések közül az emelkedett trigliceridszint (18 vs. 18\%) és a lipázemelkedés (13 vs. 12\%) a leggyakoribbak [18].

\section{Temsirolimus}

A Global Advanced Renal Cell Carcinoma (Global ARCC) vizsgálat eredménye alapján a temsirolimus okozta leggyakoribb mellékhatások százalékos megoszlása a következő volt: gyengeség (51\%), bőrpír (47\%), anaemia $(45 \%)$, hányinger $(37 \%)$, étvágytalanság $(32 \%)$, infekciók $(27 \%)$, diarrhoea $(27 \%)$, perifériás oedema (27\%), vérzsíremelkedés (27\%), emelkedett vércukorszint $(26 \%)$ és köhögés (26\%). Nem elhanyagolható a nyálkahártya-gyulladás (20\%) és vesemúködési zavarok (25\%) előfordulási gyakorisága sem. Grade 3-4 fokozatú nemkívánatos események közül a vérszegénység (20\%), a hyperglykaemia (11\%) és a dyspnoe (9\%) előfordulása számottevő. Temsirolimus-monoterápiát 209 beteg kapott, négy esetben fordult elő a kezelés során pneumonitis, amely egy esetben vezetett halálhoz [19].

Bélperforáció fokozott veszélye miatt láz, hasi panaszok és melaena esetén mindenképpen szükséges a hasi történés kizárása.

Laborvizsgálatok kapcsán kiemelkedő jelentőségű a vesefunkció, a vérzsír- és vércukor-paraméterek gondos monitorozása, szükség esetén kezelése.

A pneumonitis veszélye miatt rendszeres radiológiai követés is indokolt. Aszimptomatikus folyamat esetén a terápia felfüggesztése vagy a dózis módosítása nem szükséges, de tünetes esetekben mindenképpen megfontolandó.

\section{Everolimus}

A RECORD-1 fázis III vizsgálat adatai szerint a stomatitis/mucositis (44\%) és a különböző infekciók (27\%) voltak a leggyakoribb mellékhatások. A 3-4-es fokozatúak közül ugyancsak a fertőzés (10\%), valamint a nehézlégzés $(7 \%)$ és a fáradékonyság $(5 \%)$ említésre méltó.

Laboratóriumi eltérések igen nagy gyakorisággal fordultak elő: anaemia (92\%), leukopenia (51\%), koleszterinszint-emelkedés (77\%), trigliceridszint-eleváció (73\%) és magas vércukorszint (57\%). A grade 3-4 fokozatú nemkívánatos események közül az anaemiát (13\%), a leukopeniát (11\%), illetve a hyperglykaemiát (16\%) lehet kiemelni.

Nem fertőzés okozta pneumonitist 37 esetben jelentettek. A folyamat köhögéssel (51\%), légszomjjal (43\%) vagy mindkettővel (32\%) társult [20].

A szájnyálkahártya-elváltozások és infekciók fokozott veszélye miatt a betegek felvilágosítása, az elváltozások lokális kezelése szükségszerû. Alkohol- vagy peroxidtartalmú szájvizek és gombaellenes készítmények (gombafertőzés hiányában) kerülendők. A pneumonitis kezelési stratégiáját a társuló tünetek határozzák meg. Súlyosabb esetekben a terápia felfüggesztése és kortikoszteroidok adása indokolt.

A nagyszámú laborabnormalitások lehetősége miatt a vérkép és vérkémia rendszeres ellenőrzését sem lehet eléggé hangsúlyozni.

\section{Nivolumab}

A nivolumabkezelés okozta mellékhatások a hatásmechanizmusnak megfelelően elsősorban immunrendszeri eredetúek.

A tüdőben interstitialis tüdőbetegséget, pneumonitist okozhat. A kórkép köhögést és nehézlégzést eredményezhet, illetve különböző radiológiai eltérések (foltos infiltráció, fokális tejüvegszerű homály) formájában jelenhet meg.

Hasmenés és colitis (vizes, híg, laza széklet, hasi fájdalom, súlyosabb esetekben nyákos vagy véres széklet) jelentkezhet.

Az immunrendszer-eredetű hepatitis megnyilvánulhat fáradtság, jobb oldali hasi fájdalom és icterus formájában, valamint a bilirubin- és a transzaminázszintek emelkedésében.

A nephritis és egyéb vesemúködési zavarok esetén figyelemfelkeltő lehet a vizelet mennyiségének csökkenése és a vesefunkciós értékek emelkedése.

A hormonháztartást érintő nemkívánatos események közül a pajzsmirigybetegségek, a mellékvese-elégtelenség, a diabetes mellitus és a hypophysitis emelhetők ki. A hypothyreosis vagy hyperthyreosis előfordulási gyakorisága a többi endokrin szerv érintettségéhez képest nagyobb. A hormonális eltérések okozta tünetek és panaszok szerteágazóak: fáradtság, testtömegváltozás, fejfájás, a mentális státusz megváltozása, hasi fájdalom, 
széklethabitus-változás, látászavar, kifejezett szomjúság, polyuria, hypotensio, depresszió, ingerlékenység és gyengeség.

A bőrelváltozások (maculopapularis, erythematosus, follicularis, pustularis és vesicularis bőrkiütések, valamint dermatitis acneiformis, dermatitis allergica és dermatitis exfoliativa) előfordulási gyakorisága viszonylag magas.

Egyéb immunrendszeri eredetú mellékhatások közül ritkán előfordult pancreatitis, uveitis, demyelinisatio, Guillain-Barré-szindróma és autoimmun neuropathia. Minden esetben törekedni kell a fertőzés okozta és a betegséggel összefüggő eredet kizárására.

A mellékhatások medián jelentkezési ideje a következőképpen írható le: 6-7. hét/4. dózis - hyperthyreosis; 8-9. hét $/ 5$. dózis - pneumonitis; $10-11$. hét $/ 6$. dózis - kezelés; 12-13. hét/7. dózis - hepatitis; 14-15. hét/8. kezelés - vesemúködési zavar [27].

A CheckMate 025 klinikai vizsgálatban a nivolumabkaron levő betegek 79\%-ánál jelentkezett valamilyen mellékhatás. A leggyakoribbak a fáradékonyság (30\%), hányinger $(14 \%)$, bőrviszketés (14\%), hasmenés (12\%), bőrkiütés (10\%), köhögés $(9 \%)$, nehézlégzés $(7 \%)$, perifériás oedema (4\%) és a pneumonitis $(4 \%)$ voltak. Grade 3-4 mellékhatás összesen a betegek 19\%-ánál jelentkezett, a leggyakoribb a fáradékonyság volt $-2 \%$. A kezelést, mellékhatások miatt, mindössze az esetek 8\%-ában kellett abbahagyni [21].

\section{A gyakori, klinikailag jelentős mellékhatások és kezelésük}

\section{Hypertonia}

A magas vérnyomás a direkt VEGF-gátlással összefüggésbe hozható, on-target mellékhatás, amely valamenynyi, VEGF-receptoron ható TKI-kezelés gyakori velejárója (bevacizumab, sunitinib, sorafenib, pazopanid, axitinib, cabozantinib és lenvatinib). A folyamat patofiziológiája nem teljesen tisztázott, de a gyógyszerek, feltételezhetően az endothelin-1-rendszer aktiválódásán, a renin-angiotenzin rendszer, valamint az endothelialis nitrogén-oxid-szintáz gátlásán és a perifériás érellenállás növelésén keresztül vezetnek hypertensio kialakulásához. TKI-val kezelt vesetumoros betegek között 1745\%-os arányban írtak le hypertoniát, és grade 3-4 fokozatú az esetek 3-16\%-a volt. A magas vérnyomás tipikusan korai mellékhatás, már a kúra harmadik-negyedik hetében jelentkezni szokott. A terápia megkezdése előtt szükséges a betegek vérnyomásának rögzítése, majd a kezelés során folyamatos monitorozása. Amennyiben a TKI-kezelés során a korábban antihipertenzív kezelésben nem részesülő betegeknél hypertonia alakul ki, vagy az ismert és kezelt magas vérnyomásos páciensek diasztolés értéke több mint $20 \mathrm{Hgmm-rel} \mathrm{növekszik,}$ vérnyomáscsökkentő(k) adására, a korábbi terápia módosítására/kiegészítésére, esetleg a TKI dózásnak redukálására vagy adagolási sémájának módosítására van szükség. A tenzió beállítására a vérnyomáscsökkentők valamennyi fớbb típusa használható - angiotenzinreceptor-blokkolók, ACE-gátlók, béta-blokkolók, kalciumcsatorna-blokkolók és diuretikumok. Nem rendelkezünk egyértelmű ajánlással arra vonatkozólag, hogy melyik csoport lenne az ideális, a mindenkori gyógyszerválasztást a betegek státuszának megfelelően kell indikálni, például metabolikus szindrómás, krónikus vesebetegségben szenvedőknek vagy fehérjevizelőknek ACE-gátlók adása javasolt [28-31].

\section{Egyéb on-target mellékhatások}

A hypertoniához hasonlóan, a direkt VEGF-gátlással hozható összefüggésbe a proteinuria, a sebgyógyulási zavarok, valamint a különböző vérzéses és thromboemboliás szövődmények.

A fehérjevizelés patomechanizmusa nem ismert pontosan, de feltételezhetően a VEGF glomerularis endothel repairben betöltött szerepével van összefüggésben. Proteinuriát elsősorban a bevacizumab okoz, grade 4 fokozat esetén a terápia befejezése indokolt [32].

Különböző vérzéses tünetek - epistaxis, haematemesis, gyomor-, rectalis vagy cerebralis vérzés - is bevacizumabkezelés mellékhatásaként fordulnak elő leggyakrabban, olykor fatális kimenetelüek is lehetnek. Sebgyógyulási zavarokról legnagyobb számban bevacizumabbal vagy pazopanibbal kezelt eseteknél számoltak be $[30,32]$.

Thromboemboliás események rizikója az angiogenezist gátló modalitások alkalmazása mellett növekszik, vonatkozik ez az artériás (ATE) és vénás (VTE) thromboemboliás szövődményekre egyaránt. A patomechanizmus itt is a VEGF endotheljavító múködésével lehet kapcsolatban. Különböző klinikai vizsgálatok adatainak feldolgozása alapján megállapítható volt, hogy a VTE elsősorban a bevacizumab-, az ATE a sunitinib- és sorafenibkezelésekkel volt kapcsolatba hozható [30].

\section{Cardiovascularis mellékhatások}

A TKI-kezelések okozta toxikus hatások közé tartozik a hypertonia, a perifériás oedema és a különböző kardiális események. A VEGFR-, PDGFR-, RAF-1- és c-KITutak blokkolásán olyan intracelluláris javítófunkciók károsodhatnak, amelyek a szívizomsejtek apoptózisát okozhatják. A panaszok változatosak, szédülés, nehézlégzés és mellkasi fájdalom jelentkezhet. Azoknál a pácienseknél, akiknek anamnézisében korábbi koszorúér-betegség szerepel, mind a sunitinib, mind a sorafenib mellékhatásaként a bal kamrai ejekciós frakció (LVEF) csökkenésével járó congestiv szívbetegség alakulhat ki. Az mRCC kezelésére használt TKI-készítmények közül a sunitinib okozhat legnagyobb arányban bal kamrai elégtelenséget, akár olyan betegnél is, akinek korábban nem volt ismert szívbetegsége. A kezelés megkezdése előtt, majd a kúra során időszakosan indokolt a kardiális 
állapot (EKG és szívultrahang) felmérése, fóleg akkor, ha a betegek 12 hónapon belüli kórelőzményében hypertonia, koszorúér-betegség, diabetes vagy egyéb vascularis történés szerepel. Amennyiben az LVEF 50\% alá vagy a kiindulási értékhez képest legalább 20\%-kal csökken, a terápia időszakos vagy végleges felfüggesztése indokolt. A sunitinib QT-megnyúlást is okozhat, amely fokozza a kamrai ritmuszavarok, elsősorban a torsade de pointes (<1\%) veszélyét. Emiatt fokozott odafigyelést igényelnek azok a betegek, akiknek anamnézisében QT-megnyúlás, korábbi ritmuszavar, antiarrythmiás kezelés vagy elektrolit- $\left(\mathrm{K}^{+}, \mathrm{Mg}^{++}\right)$zavarok szerepelnek $[28,30,31]$.

\section{Fáradékonyság, testsúlyvesztés}

A VEGF-gátló kezelések mellékhatásaként igen nagy arányban (19-77\%) fordul elő az általános gyengeség, de a grade 3-4 fokozat ritkábban (11-12\%). Az mTOR-gátlók közül az everolimus ugyancsak okozhatja. Patomechanizmusában mind a pajzsmirigy-alulmúködés, mind a vérszegénység, mind a dehidráció, mind a kísérő betegségek és depresszió szerepet játszhat. Sunitinib- és sorafenibkezelés esetén a hypogonadismus lehetősége is felmerül. A lehetséges kiváltó okok szupportív ellátása mellett elsősorban a betegek felvilágosítására és motiválására kell nagy hangsúlyt fektetni, hogy olyan megvilágításban lássák e panaszukat, amely egy szükséges, de elviselhető rossz, a nagy terápiás előnnyel rendelkező kezelés árnyékában. Természetesen, ha szükséges, a dózis csökkentése és az adagolási séma módosítása is szóba jöhet [30, 31].

Tartós fogyás esetén progeszteronszármazék, megesztrol-acetát (160-800 mg/nap) vagy dexamethason (4 mg) adható [31].

\section{Gastrointestinalis (GIT) mellékhatások}

A GIT-mellékhatások közül a hasmenést, a hányingert és hányást kell megemlíteni. A terápia befejezéséhez vagy a dózis módosításához ritkán vezetnek, rendszerint nem súlyosak és hatásosan menedzselhetők.

Diarrhoea jelentkezése esetén diétás javaslatokkal kell a betegeket ellátni, esetleg dietetikus tanácsát kérni. Ajánlott a napi többszöri, kis mennyiségű étkezés és folyadékbevitel, több burgonya és rizs fogyasztása, a zsíros, füszeres, magas rost-, koffein- és laktóztartalmú ételek kerülése, a korábbiakban alkalmazott székletlazítók és hashajtók elhagyása. Az étrendbe a gyümölcsök közül csak a banán és a reszelt alma beiktatása javasolható, amelyek magas pektintartalmuknál fogva hasmenésgátló hatásúak. Súlyosabb esetekben, amennyiben a diéta nem eredményes, loperamid szedése javasolható ( $2 \mathrm{mg}$ négyóránként az első 12-24 órában, majd minden lazább széklet után $4 \mathrm{mg}$ ). A dózis szükség szerint emelhető 2 mg kétóránként. Súlyosabb esetben három-négy óránként, egy teáskanál opiáttartalmú tinktúra (kodein vagy morfin), esetleg budesonid adható. Grade 1-2 fokozatú esetekben dóziscsökkentés nem indokolt, 3-4 fokozat esetén a kezelés felfüggesztése javasolt. Visszatérő grade 3-as diarrhoea esetén dózisredukció, 4-es súlyossági fokozat esetén a terápia befejezése szükséges [31].

Hányinger vagy hányás ritkán jelentkezik súlyos mellékhatásként. Megelőzésére kis dózisú szteroid- vagy antidopaminerg készítmények javasolhatók [31]. Megjegyzendő, hogy a sunitinib utóbbiakkal együtt QT/QTc megnyúlást eredményezhet!

\section{Pajzsmirigy-müködési zavarok}

A VEGFR-1 és -2 recetorok blokkolásán keresztül számos TKI- (sunitinib-, axitinib-, sorafenib-) kezelés okoz pajzsmirigy-alulmúködést, átlagosan körülbelül 14\%-os gyakorisággal. A pontos mechanizmus nem teljesen tisztázott, de a hatás kialakulhat egyaránt mind a follicularis sejtek elhalása okozta destruktív thyreoditisen, mind endothelialis diszfunkción, mind a jódfelvétel gátlásán, valamint a hormonszintézis csökkenésén keresztül. A kúra megkezdése előtt, valamint a kezelés folyamán egy-három havonta TSH-meghatározás szükséges. A hypothyreosis egyéb mellékhatások kialakulásában (gyengeség és fáradékonyság) is közrejátszhat, ezért tüneteket és panaszokat okozó esetekben korrekciója indokolt. Orális hormonszubsztitúcióval az eltérés jól kezelhető [28-31].

\section{Orális elváltozások, mucositis és stomatitis}

A szájnyálkahártya elváltozásai, úgymint érzékenység, ízérzészavar, szájszárazság és gyulladás gyakori mellékhatásai a TKI-kezeléseknek. Megelőzés céljából puha sörtéjü fogkefe és gyermekfogkrém használata javasolható. Kialakult tünetek esetén, kevésbé súlyos esetekben, vizes vagy kamillás öblögetés, dexpanthenol, fájdalmas szájlaesiók esetén paracetamol-, morfin- vagy kodeintartalmú, bikarbonátalapú szájvíz alkalmazása ajánlott. A járulékos keilitis kezelésére akár lidocaintartalmú ajakkrém vagy -balzsam használatára is szükség lehet. Elhúzódó esetekben dózisredukciókra vagy a kezelés halasztására is sor kerülhet. Az mTOR-gátlók okozta nyálkahártya-elváltozások rendszerint enyhék, kezelésük nem tér el a TKI-k hasonló mellékhatásainak ellátásától [29, 31].

\section{Börelváltozások}

A dermatológiai nemkívánatos események a VEGFR és PDGFR, bőr/haj depigmentáció az SCF- és c-KIT-utak blokkolásán keresztül jöhetnek létre. TKI-készítmények közül leggyakrabban (több mint 50\%-ban) a sorafenib okozza. A hatásmechanizmus itt sem pontosan definiált, de valószínúsíthetően az említett receptorok gátlása a bőr endothelialis sejtjeinek elhalását és verejtékmirigyeinek károsodását okozza. Legjellemzőbb előfordulási formája a kéz-láb szindróma (HFS), de tolószékben ülő betegeknél a nyomásnak leginkább kitett pontokon, azaz a farpofákon és a gáton jön létre. 
Miután pigmentációs zavarok megelőzésére nincs nagyon lehetőség, fontos a betegek előzetes tájékoztatása/felkészítése az esetlegesen bekövetkező hajszínváltozásra, illetve a bőr halvány (zöldes)sárga elszíneződésére.

A HFS-prevenció szempontjából fontos a nyomásnak kitett testrészek kímélete, a talpak és kezek súrlódás és kidörzsölődés elleni védelme. Még a terápia megkezdése előtt indokolt egy alapos lábfejvizsgálat és lábápolás (pedikűr) a hyperkeratoticus elváltozások eltávolítása céljából. Grade 1 HFS jelentkezése esetén vastag talpú cipő viselése, szteroid-, A-vitamin-, szalicilsav- vagy ureatartalmú krémek használata ajánlható. Kedvező tapasztalatokról számoltak be a betegek olyan zsíros krémek használatával kapcsolatban, amelyek shea- (kelet-indiai olajfa) vajat, mangóvajat, levendulát, kendermagolajat, olívaolajat, méhviaszt, lecitint, aloe verát vagy $\mathrm{D}$-pantenolt tartalmaztak. Grade 2 fokozat esetén indokolt a kúra megszakítása és a graduscsökkenés (0-1) utáni folytatása, 3-as súlyossági fokozat jelentkezése esetén, főleg, ha már többedik alkalommal fordul elő, javulást követően az alkalmazott dózis csökkentése javasolt. A hólyagos bőrelváltozások bőrgyógyászati ellátása és hidrokolloidos kötözése szükséges.

Az mTOR-gátló gyógyszerek mellékhatásaként jelentkező bőrelváltozások maculopapolosus jellegüek és rendszerint alacsony fokozatúak [28-31].

\section{Hematológiai mellékhatások}

A myeloszuppresszió is VEGF-szignálutak befolyásolásával, feltételezhetően olyan intracelluláris autokrin mechanizmusok érintettségével jön létre, amelyeken keresztül a VEGF hatást gyakorol a haemopoeticus őssejtek élettartamára. A TKI-kezelések esetén leukopenia, thrombocytopenia és anaemia egyaránt előfordulhat. Sunitinibkezelés során a vérlemezkeszám-csökkenés tipikusan az első ciklus folyamán jelentkezik, de a további kúra folyamán már nem rosszabbodik. Az anaemia sok esetben nem is gyógyszeres kezeléssel, hanem az alapbetegséggel hozható összefüggésbe. A lehetséges hematológiai mellékhatások miatt, legalább minden ciklus kezdetén, panaszok - láz, megfázás, vérzésre vagy fertőzésre utaló tünetek - esetén azonnal vérképkontroll indokolt. Grade 4 neutropenia esetén profilaktus antibiotikus kezelés és kolóniastimuláló faktor (G-CSF) adása válhat szükségessé. Grade 2-3 leukopenia vagy thrombocytopenia esetén a soron következő ciklus megkezdésének halasztása, elhúzódó esetekben dóziscsökkentés ajánlott. Vérszegénység esetében elsődlegesen kizárandók azok a hiányállapotok - vas, $\mathrm{B}_{12}$-vitamin, folsav -, amelyek egyszerúen szubsztituálhatók [30, 31].

\section{Metabolikus zavarok}

Anyagcsere-eltéréseket jellemzően az mTOR-gátló készítményekkel történő kezelések mellékhatásaként észlelünk, jellemzően a PI3K/Akt, az mTORCl és
mTORC2 receptorokon keresztül jönnek létre. A szérum vércukor- és vérzsírértékeinek emelkedése, illetve a foszforszint csökkenése a leggyakoribbak. Bár ilyen irányú direkt összehasonlító vizsgálat nem történt, feltételezhető, hogy e nemkívánatos események tekintetében a temsirolimus és az everolimus mellékhatásprofilja hasonló. Az éhgyomri vércukor-, a hemoglobin-A-lc-, koleszterin- és trigliceridszintek szoros követése szükséges. Figyelemfelkeltő lehet a vizelet mennyiségének és az ürítés gyakoriságának fokozódása, valamint az állandósuló szomjúságérzet. A diéta módosításával, a cukor- és zsírbevitel csökkentésével, szükség esetén célirányos gyógyszeres kezeléssel az eltérések korrigálhatók $[29,31]$.

\section{Pneumonitis, interstitialis tüdöbetegség}

Bár nem gyakori mellékhatás, már a temsirolimus fázis I-II vizsgálatai során jelentettek néhány fatális kimenetelü esetet, a fázis III vizsgálatban a betegek $2 \%$-a volt érintett. Az everolimusszal kezelt betegek körében gyakoribb, a klinikai vizsgálatok során előfordulási gyakorisága 6-13\%, retrospektív radiológiai analízis szerint 54\% volt. Légúti panaszok, rossz közérzet, nehézlégzés vagy köhögés esetén mellkas röntgen/CT, illetve légzésfunkciós vizsgálat elvégzése jöhet szóba. Ellátására vonatkozó egységes ajánlással nem rendelkezünk, de az általános gyakorlat szerint, radiológiai pozitivitás, panaszmentesség esetén a terápia folytatása, tünetes esetekben a kúra időleges megszakítása javasolható. Súlyosbodó panaszok, romló általános állapot mellett a terápia befejezése és nagy dózisú szteroid adása szükséges $[28,29,31]$.

\section{Immunterápia okozta mellékhatások}

A checkpoint inhibitorok okozta mellékhatások ellátását elsősorban a súlyossági fok határozza meg. Grade 1-2 fokozatú tünetekkel rendelkező betegek kórházi felvételt nem igényelnek, grade 3-4 esetén kórházi, szükség esetén intenzív osztályos felvétel válhat szükségessé. Grade 1 esetén sem a terápia felfüggesztése, sem kezelés nem indokolt. Grade 2 fokozatú mellékhatás esetén helyi vagy szisztémás szteroidkezelés $(0,5-1 \mathrm{mg} / \mathrm{ttkg} / \mathrm{nap})$, a kezelés átmeneti felfüggesztése szükséges. Ha a tünetek grade 1-re csökkennek vagy megszúnnek, illetve a napi szteroiddózis a napi $10 \mathrm{mg}$ prednisolon vagy az azzal ekvivalens szteroiddózist nem haladja meg, a kezelés folytatható. Grade 3 fokozat esetén szisztémás methylprednisolonkezelés (1-2 $\mathrm{mg} / \mathrm{ttkg} /$ nap) szükséges, és amennyiben a tünetek három-öt napon belül nem javulnak, egyéb immungátló készítmények adása, a kúra folytatásának mérlegelése javasolt. Visszatérő grade 3 és grade 4 esetekben mindenképpen a kezelés végleges felfüggesztése szükséges [27, 33, 34]. 


\section{Mellékhatások mint lehetséges biomarkerek}

A terápiás gyakorlatba került terápiás készítmények palettájának bővülésével párhuzamosan egyre több tudományos értekezés került publikálásra, amelyek a célzott kezelések okozta mellékhatások és klinikai hatékonyság közötti összefüggéseket vizsgálták.

Kisebb-nagyobb arányban valamennyi TKI-kezelés mellékhatásaként jelentkezhet hypertonia. Retrospektív vizsgálatok alapján több terápiás modalitás - sunitinib, bevacizumab, axitinib és tivozanib - esetében is szignifikáns terápiás előny (hosszabb PFS és OS) mutatkozott azoknál a betegeknél, akiknél a kúra mellékhatásaként vérnyomás-emelkedés következett be. Ez az összefüggés mind az összes, mind a grade 3-4 fokozatú eseteknél megfigyelhetó volt $[28,30,31]$.

A pajzsmirigy-alulmúködés vonatkozásában hasonló összefüggés mutatkozott sunitinib- és sorafenibkezelések során [29, 32, 35].

Prospektív klinikai vizsgálatok adatainak visszamenőleges analízise szerint a kéz-láb szindróma (HFS) kialakulása is prediktív lehet sunitinibterápia esetén. Sunitinibbel kezelt 770 beteg adatainak feldolgozása alapján, mind az OS (38,2 vs. 18,9 hónap), mind a PFS (14,3 vs. 8,3 hónap) szignifikánsan jobbnak bizonyult a HFS-csoportban [29, 32, 35].

Ugyancsak sunitinibbel kezelt betegek adatainak feldolgozása alapján bebizonyosodott, hogy a fáradékonyság/gyengeség kialakulása és a terápiás effektivitás között is pozitív korreláció volt. Megjegyzendő azonban, hogy a fáradékonyság kialakulásában számos egyéb tényező (társbetegségek, egyéb gyógyszerek, hypothyreosis, anaemia, valamint az ugyancsak VEGF-gátlók okozta hypogonadismus) is szerepet játszhatott $[29,35]$.

Számos olyan publikáció is közlésre került, amelyek TKI-kezelés okozta hasmenést, a kéz-láb szindrómán kívüli egyéb dermatológiai eltéréseket (például rash), a mucositist, a leuko- és thombocytopeniát, a vesefunkciós értékek romlását, valamint számos egyéb laboreltérést azonosítottak mint lehetséges prediktív faktort [29, 32].

A jellemzően mTOR-gátló terápia okozta mellékhatások közül elsősorban a pneumonitis jöhet számításba mint biomarker. Temsirolimusszal és everolimusszal kezelt betegek bevonásával végzett két, egyesült államokbeli vizsgálatban a tüdőelváltozás 30\%-os gyakorisággal fordult elő. Közülük csak 14\% volt progresszív betegség, 86\%-ban stabil folyamat volt észlelhető. Pneumonitis nélkül az arány $56 \%$ vs. $44 \%$ volt az előbbi javára [35].

Szintén az mTOR-gátló készítményekhez köthető metabolikus eltérések közül egyes vizsgálatok a koleszterintszint, más vizsgálatok a vércukor- és a trigliceridszintek emelkedését hozták összefüggésbe a terápiás válaszszal [35].

Osztályunkon, 2010 és 2014 között, sunitinibbel elsó vonalban kezelt 274 beteg adatainak retrospektív analízise alapján szignifikáns pozitív korrelációt találtunk a PFS-növekedés és a hypertonia, a hasmenés, a kéz-láb szindróma, a hypothyreosis, az egyéb bőrtünetek és a leukopenia előfordulása között. Hosszabb túlélés szempontjából is szignifikánsak voltak ugyanezek a mellékhatások, valamint a thrombocytopenia is. A hepaticus eltérések és a vérszegénység inverz markernek bizonyult, az anaemia előfordulása esetén a PFS és az OS is szignifikánsan rövidebb volt, a hepatotoxicitas esetén csak progressziómentes túlélés vonatkozásában. Az adatok összegzése alapján úgy tapasztaltuk, hogy a fent említett mellékhatások száma is prediktív markernek bizonyult, azaz minél több mellékhatás jelentkezik egy páciensben, annál nagyobb a klinikai hatékonyság [36].

A terápiás effektus és mellékhatások közötti feltételezett összefüggések retrospektív vizsgálatokon alapulnak, prospektív validálásuk még nem történt meg.

\section{Következtetés}

A vesesejtes daganatok kezelésében meghatározó szerepet töltenek be a célzott terápiás készítmények. Hazánkban szinte valamennyi, a nemzetközi ajánlásokban szereplő készítmény rendelhető, igaz, a NEAK részéről csak két terápiás vonal finanszírozott. Tetszőleges számban vagy szabadon választott szekvencia szerint továbbra sem adhatók a gyógyszerek, de ennek ellenére is egyre több tapasztalathoz jutnak a kezelőorvosok, egyre jobban megismerik az adott termék mellékhatásait. Miután számos adat áll rendelkezésre arról, hogy az adott készítmények okozta bizonyos mellékhatások előfordulása prediktív értékkel bírhat a kedvező terápiás effektusra vonatkozva, nagyon fontos a nemkívánatos események korai felismerése és szakszerű ellátása, valamint a betegek tájékoztatása, a gyógyszer megismertetése. Közös célunk, hogy a kezelt betegek minél tovább maradjanak aktív terápián, fơleg jó klinikai hatékonyság esetén, ne a mellékhatások miatt kelljen a kúrát leállítani vagy a dózist az eredményességet veszélyeztető módon csökkenteni.

Anyagi támogatás: A közlemény megírása anyagi támogatásban nem részesült.

Szerzői munkamegosztás: N. K.: A cikk megírása. G. L.: Tanácsadás, útmutatás. A cikk végleges változatát mindkét szerző elolvasta és jóváhagyta.

Érdekeltségek: A szerzőknek nincsenek érdekeltségeik.

\section{Irodalom}

[1] Siegel RL, Miller KD, Jemal A. Cancer statistics, 2016. CA Cancer J Clin. 2016; 66: 7-30.

[2] Leibovich BC, Lohse CM, Crispen PL, et al. Histological subtype is an independent predictor of outcome for patients with renal cell carcinoma. J Urol. 2010; 183: 1309-1315.

[3] Chow WH, Dong LM, Devesa SS. Epidemiology and risk factors for kidney cancer. Nat Rev Urol. 2010; 7: 245-257. 
[4] Escudier B, Porta C, Schmidinger M, et al. Renal cell carcinoma: ESMO Clinical Practice Guidelines for diagnosis, treatment and follow-up. Ann Oncol. 2016; 27(Suppl 5): v58-v68.

[5] Zarrabi K, Fang C, Wu S. New treatment options for metastatic renal cell carcinoma with prior anti-angiogenesis therapy. J Hematol Oncol. 2017; 10: 38

[6] Motzer RJ, Nosov D, Eisen T, et al. Tivozanib versus sorafenib as initial targeted therapy for patients with metastatic renal cell carcinoma: results from a phase III trial. J Clin Oncol. 2013; 31: 3791-3799.

[7] Gordon MS, Hussey M, Nagle RB, et al. Phase II study of erlotinib in patients with locally advanced or metastatic papillary histology renal cell cancer: SWOG S0317. J Clin Oncol. 2009; 27: 5788-5793.

[8] Escudier B, Bellmunt J, Négrier S, et al. Phase III trial of bevacizumab plus interferon alfa-2a in patients with metastatic renal cell carcinoma (AVOREN): final analysis of overall survival. J Clin Oncol. 2010; 28: 2144-2150.

[9] Rini BI, Halabi S, Rosenberg JE, et al. Phase III trial of bevacizumab plus interferon alfa versus interferon alfa monotherapy in patients with metastatic renal cell carcinoma: final results of CALGB 90206. J Clin Oncol. 2010; 28: 2137-2143.

[10] Escudier B, Eisen T, Stadler WM, et al. Sorafenib for treatment of renal cell carcinoma: final efficacy and safety results of the phase III Treatment Approaches in Renal Cancer Global Evaluation Trial. J Clin Oncol. 2009; 27: 3312-3318.

[11] Motzer RJ, Hutson TE, Tomczak P, et al. Overall survival and updated results for sunitinib compared with interferon alfa in patients with metastatic renal cell carcinoma. J Clin Oncol. 2009; 27: 3584-3590

[12] Sternberg CN, Davis ID, Mardiak J, et al. Pazopanib in locally advanced or metastatic renal cell carcinoma: results of a randomized phase III trial. J Clin Oncol. 2010; 28: 1061-1068.

[13] Sternberg CN, Hawkins RE, Wagstaff J, et al. A randomised, double-blind phase III study of pazopanib in patients with advanced and/or metastatic renal cell carcinoma: final overall survival results and safety update. Eur J Cancer 2013; 49: 12871296.

[14] Motzer RJ, Hutson TE, Cella D. Pazopanib versus sunitinib in metastatic renal-cell carcinoma. N Engl J Med. 2013; 369: 722 731.

[15] Motzer RJ, Escudier B, Tomczak P, et al. Axitinib versus sorafenib as second-line treatment for advanced renal cell carcinoma: overall survival analysis and updated results from a randomised phase 3 trial. Lancet Oncol. 2013; 14: 552-562.

[16] Choueiri TK, Escudier B, Powles T, et al. Cabozantinib versus everolimus in advanced renal-cell carcinoma. N Engl J Med. 2015; 373: 1814-1823.

[17] Choueiri TK, Escudier B, Powles T, et al. Cabozantinib versus everolimus in advanced renal cell carcinoma (METEOR): final results from a randomised, open-label, phase 3 trial. Lancet Oncol. 2016; 17: 917-927.

[18] Motzer RJ, Hutson TE, Glen H, et al. Lenvatinib, everolimus, and the combination in patients with metastatic renal cell carcinoma: a randomised, phase 2 , open-label, multicentre trial. Lancet Oncol. 2015; 16: 1473-1482.

[19] Hudes G, Carducci M, Tomczak P, et al. Temsirolimus, interferon alfa, or both for advanced renal-cell carcinoma. N Engl J Med. 2007; 356: 2271-2281.

[20] Motzer RJ, Escudier B, Oudard S, et al. Phase 3 trial of everolimus for metastatic renal cell carcinoma: final results and analysis of prognostic factors. Cancer 2010; 116: 4256-4265.
[21] Motzer RJ, Escudier B, McDermott DF, et al. Nivolumab versus everolimus in advanced renal-cell carcinoma. N Engl J Med. 2015; 373: 1803-1813.

[22] NCCN Clinical Practice Guidelines in Oncology (NCCN Guidelines): Kidney Cancer, Version 2.2017 - October 31, 2016 NCCN.orgVersion 2.2017, 10/31/16 @ National Comprehensive Cancer Network, Inc. 2016.

[23] Escudier B, Porta C, Bono P, et al. Randomized, controlled, double-blind, cross-over trial assessing treatment preference for pazopanib versus sunitinib in patients with metastatic renal cell carcinoma: PISCES study. J Clin Oncol. 2014; 32: 1412-1418.

[24] 31/2010. (V. 13.) Health Ministry Decree of the Financing Procedures. Par 2 (2) The procedure for financing the diagnosis and treatment of clear cell carcinoma can be found in Annex 2. (3) The procedure for financing the diagnosis and treatment of nonclear cell kidney tumors is set out in Annex 3. [31/2010. (V. 13.) EüM rendelet a finanszírozási eljárásrendekről. 2. \$ (2) A világossejtes vesedaganatok diagnosztikájának és kezelésének finanszírozási eljárásrendjét a 2. melléklet tartalmazza. (3) A nem világossejtes vesedaganatok diagnosztikájának és kezelésének finanszírozási eljárásrendjét a 3. melléklet tartalmazza. [Hungarian]

[25] Procopio G, Verzoni E, Testa I, et al. Experience with sorafenib in the treatment of advanced renal cell carcinoma. Ther Adv Urol. 2012; 4: 303-313.

[26] Gore ME, Szczylik C, Porta C, et al. Safety and efficacy of sunitinib for metastatic renal-cell carcinoma: an expanded-access trial. Lancet Oncol. 2009; 10: 757-763.

[27] Champiat S, Lambotte O, Barreau E, et al. Management of immune checkpoint blockade dysimmune toxicities: a collaborative position paper. Ann Oncol. 2016; 27: 559-574.

[28] Hutson TE, Figlin RA, Kuhn JG, et al. Targeted therapies for metastatic renal cell carcinoma: an overview of toxicity and dosing strategies. Oncologist 2008; 13: 1084-1096.

[29] Ravaud A. Treatment-associated adverse event management in the advanced renal cell carcinoma patient treated with targeted therapies. Oncologist 2011; 16(Suppl 2): 32-44.

[30] Cohen RB, Oudard S. Antiangiogenic therapy for advanced renal cell carcinoma: Management of treatment-related toxicities. Invest New Drugs 2012; 30: 2066-2079.

[31] Eisen T, Sternberg CN, Robert C, et al. Targeted therapies for renal cell carcinoma: review of adverse event management strategies. J Natl Cancer Inst. 2012; 104: 93-113.

[32] Schmidinger M, Larkin J, Ravaud A. Experience with sunitinib in the treatment of metastatic renal cell carcinoma. Ther Adv Urol. 2012; 4: 253-265

[33] Linardou H, Gogas H. Toxicity management of immunotherapy for patients with metastatic melanoma. Ann Transl Med. 2016; 4: 272 .

[34] Villadolid J, Amin A. Immune checkpoint inhibitors in clinical practice: update on management of immune-related toxicities. Transl Lung Cancer Res. 2015; 4: 560-575.

[35] Ravaud A, Schmidinger M. Clinical biomarkers of response in advanced renal cell carcinoma. Ann Oncol. 2013; 24: 29352942.

[36] Nagyiványi K, Budai B, Bíró K, et al. Synergistic survival: A new phenomenon connected to adverse events of first-line sunitinib treatment in advanced renal cell carcinoma. Clin Genitourin Cancer 2016; 14: 314-322.

(Nagyiványi Krisztián dr., Budapest, Ráth György u. 7-9., 1122 e-mail: dr.nagyivanyi@freemail.hu) 